\title{
DIE SOEKE NA 'N BYBELSE TEOLOGIE
}

\author{
PROF. DR. J. P. OBERHOLZER
}

Die Ou Testamentiese wetenskap was in die laaste dekade en ' $n$ half oorweldigend produktief. Op feitlik elke gebied van hierdie wydvertakte wetenskap met sy talle hulpdissiplines was daar lewendige aktiwiteit. Die verskyning van nuwe publikasies het 'n haas onoorsienbare stroom geword.

Die literatuur laat veral twee gebiede na vore kom waar die vakmetodiek indringende bespreking ondergaan, $\mathrm{nl}$. die eksegese en die teologie. Wat die eksegese betref, lê die klem op die gebruik van ' $n$ veelvoud van metodes in streng volgorde ${ }^{x}$.) Die plek wat die taal-analise in hierdie metodereeks moet inneem, staan nog onder diskussie, maar toon reeds groot belofte. Die beswaar wat bv. van Leeuwen noem, $\mathrm{nl}$. dat vorm en styl so 'n belangrike plek kan inneem dat die persoon van die bybelskrywers en hulle indiwiduele ervaring agter formele patrone verlore kan gaan, ${ }^{2}$ ) hou juis nie stand waar die teks vanuit elke moontlike hoek bekyk word en so tot spreke gebring word nie. Juis die taalanalise in sy onderdele sintaktiese, stilistiese, klank-, semantiese en struktuuranalise en die vasstelling van die bedoeling en horison van die teks, ${ }^{3}$ ) is ' $n$ kragtige middel om ook die besondere en individuele te belig. Daar kan met groot verwagting uitgesien word na die resultate van die nuwere eksegetiese arbeid, ook omdat daar op streng wetenskaplike wyse stap vir stap gevorder word in die rigting van die teologiese uitspraak van elke teks.

Wat die Teologie as Ou-Testamentiese dissipline betref, is daar steeds minder vastheid en sekerheid ten opsigte van die taak en metodiek, in so 'n mate dat Childs praat van 'n krisis in die Bybelse Teologie. Childs kom te voorskyn met ' $n$ verrassend eenvoudige benadering wat so vanselfsprekend lyk dat ' $n$ mens moeilik kan begryp dat daar verskil oor kan bestaan. In die hoofstuk "The Shape of a New Biblical Theology" kies hy as die mees paslike konteks van waaruit Bybelse Teologie bedryf kan word die kanon. ${ }^{4}$ ) Dit volg, sê hy, daaruit dat alle vertakkinge van die historiese Christendom bely dat Ou- en Nuwe Testament tesame die Heilige Skrif vir die Christelike kerk vorm. Om die kanon as konteks te neem, impliseer dan verder dat die Skrif geinterpreteer moet word in verhouding tot sy funksie binne die geloofsgemeenskap waarin hy geld. Daardeur word die normatiewe kwaliteit van die Bybelse tradisie erken en die

1) Vgl. my mededeling aan die predikantevergadering 1974: „Eksegese en Prediking", H.T.S. Jrg. 30, p. 129-137.

2) C. van Leeuwen, „De Oudtestamentische Wetenschap”, N.T.T., Jrg. 26, 1972, p. 228 v.

3) Vgl. G. Fohrer (red.), Exegese des A.T., 1973, p. 57-81.

1) B. S. Childs, Biblicat Theology in Crisis, 1974, p. 99 v.v. 
„profetiese taak" van die kerk reg begryp, en daaruit volg belangrike hermeneutiese implikasies vir die benadering van die Bybelteks. Op die vraag of die belydenis van 'n teologiese konteks die verwerping van die vroeëre historiese agtergronde van die Ou- en Nuwe Testament inhou, antwoord Childs: Die belydenis van die kanon as konteks berus op die aanspraak dat die naasmekaar van die twee testamente in ' $n$ bepaalde orde en vorm 'n konteks skep wat verskil van die van die twee testamente afsonderlik. Die geheel is meer as die som van die twee dele. Daar is 'n teologiese konteks gevorm wat gebruik maak van albei testamente, maar wat iets nuuts geword het.

Maar wat is die aard van die verhouding tussen die twee testamente binne die konteks van die kanon? Aan die een kant kan hulle nie geidentifiseer word in hulle onderlinge verhouding nie omdat hulle van Christus praat op verskillende wyses. Aan die ander kant kan hulle nie geskei word asof die Nuwe Testament die Ou Testament nie meer nodig het nie. Die een kan ook nie ondergeskik aan die ander gemaak word deur die kategorieë van die geskiedenis of teologie nie, want binne die konteks van die kanon is die Ou Testament nie getuienis van ' $n$ primitiewe geloofsvlak nie en het dit nie nodig om gekersten te word nie. Die Ou Testament getuig binne sy historiese konteks van Jesus Christus.

Die verwysing na die kanon as konteks spel egter nie byvoorbaat ' $n$ teologiese sisteem uit waarbinne die twee testamente geplaas word nie. Dit voorsien eerder 'n dialektiese verhouding tussen die twee, en dit bly die eksegetiese taak van die verklaarder om die presiese verband van 'n gegewe teksgedeelte binne hierdie konteks vas te stel. Die feit dat die kanon die entiteite Ou- en Nuwe Testament ongeskonde behou binne sy nuwe teologiese vorm, het belangrike implikasies vir die begrip van die verhouding van die kanonieke kontekste tot die oorspronklike historiese kontekste van die onderskeie testamente. Die Bybelse getuienis dra al die kenmerke van historiese bepaaldheid en moet daarom beluister word binne die bepaalde tyd, deur die taal- en denkpatrone, die individuele en korporatiewe persoonlikhede van die outeurs en redakteurs. Die histories-kritiese studie het dus sy funksie. Die gebruikmaking van die dialektiek tussen Ou- en Nuwe Testament binne die konteks van die kanon verhoed dat die beweging tussen die testamente net in een rigting gesien word, $\mathrm{nl}$. van Ou- na Nuwe Testament. Dit is ' $n$ wydverspreide dwaling om die historiese bepaaldheid van die Ou Testament te erken maar die Nuwe Testament te sien as "die tydelose interpretasie" wat oor historiese beperkings heen strek. Die vorming van die kanon is ' $n$ erkenning van die noodsaak van ' $n$ konteks, onderskeie van albei testamente, waarin die Christelike kerk voortgaan om in elke nuwe eeu te worstel met die lewende 
God wat sy volk bly konfronteer met die ou getuienis van die profete en apostels.

Wanneer Childs dan kom by die metodes van die Bybelse Teologie, kies hy eerstens vir 'n begin met die Ou-Testamentiese teksgedeeltes wat in die Nuwe Testament aangehaal word. Die voordele daarvan is dat die Nuwe Testament alreeds hierdie wyse van Bybelse Teologie beoefen, dat ' $n$ mens daardeur van die begin af met ' $n$ eg Bybelse kategorie begin, dat die gebruik van aanhalings baie duidelik die verskillende maniere aantoon waarop ' $n$ teks binne 'n konteks funksioneer, en dat laastens die teologiese taak van die oorweging van die verskillende Bybelse getuies vanuit die kanonieke konteks makliker is as daar met dieselfde teks gehandel word. Childs behandel ook die besware teen so ' $n$ werkmetode en beklemtoon dat hy dit nie as enigste metode voorhou nie.

In deel III van sy „Biblical Theology in Crisis" voorsien Childs ons van enkele resultate van sy voorgestelde metodiek: Ps. 8 is ' $n$ loflied waarin die psalmis die plek van die mens as heer van die skepping as gevolg van die wil van God vasstel. Die psalm is 'n lofprysing aan God die Skepper wat in sy oneindige wysheid en mag die mens oor sy skepping gestel het. In Heb. 2:6 v.v. gee die Nuwe Testament as gevolg van die Griekse vertaling van die $\mathrm{Ou}$ Testament ' $n$ heeltemal anderste interpretasie aan die psalm. Dit word 'n Christologiese proefteks vir die Seun van die Mens wat vir 'n kort tydjie verneder was maar toe deur God verhoog is om die verteenwoordiger van elke mens te wees. Die Christelike skrifverklaarder moet nou in die eerste plek die getuienis van albei tekste so duidelik moontlik probeer hoor, maar in hulle verhouding tot mekaar. Tweedens moet hy in die tekste probeer indring en met die werklikheid wat albei voortgebring het, worstel. Om dan ' $n$ brug te slaan tussen die Ou- en Nuwe Testamentiese gebruik van Ps. 8, moet uitgegaan word van die vraag: Hoe sien die Ou Testament as geheel die probleem van die mens as skepping van God en die mens in die werklike lewe? Binne die Ou Testamentiese konteks word hierdie probleem telkens belig, o.a. in Job en Prediker. (Job 7:16-19: „Ek verfoei my lewe. Nie vir altyd sal ek lewe nie: laat my met rus, want my dae is nietigheid. Wat is die mens dat $U$ hom so hoog stel en op hom ag gee? ... Hoe lank sal $U$ nie van my af wegkyk nie, my nie laat staan nie totdat ek my speeksel insluk?" Pred. 3:11, 19: "Alles het Hy mooi gemaak op sy tyd; ook het $\mathrm{Hy}$ die eeu in hulle hart gelê sonder dat die mens die werk wat God doen, van begin tot end, kan uitvind... Want die lot van die mensekinders is ook die lot van die veediere; soos die een sterwe, so sterwe die ander...") Dit is eers wanneer ' $n$ mens die belydenis van Ps. 8 in hierdie lig hoor, dat 'n mens kan begryp wat die Nuwe Testamentiese skrywer doen. Hy staan voor die probleem van die rol wat aan die mens toegesê is en die mens soos hy werklik is, en hy getuig 
van die werk van God in die Seun van die Mens. Eers wanneer die mens verstaan word in die lig van die mens Jesus Christus, word dit duidelik wat God die mens bedoel het om te wees. Dit beteken dat die Nuwe Testament die basiese probleem agter die Ou Testamentiese getuienis raaksien in die lig van Jesus Christus en sy eie duidelike getuienis gee: Eerstens, die psalmis was reg in sy belydenis van die besondere rol van die mens in die skepping. Tweedens, die wyse waarop die mens hierdie ereposisie bereik, is deur lyding en dood. Daar is ' $n$ kloof wat hom skei van die rol waarvoor hy bedoel is. Die mens het homself verloor en onderworpe geraak aan die bedreiginge van die wêreld. Derdens, as gevolg van Jesus se werk word die mens uitgenooi om toe te tree tot die volle eer van sy regmatige plek in verhouding tot God. As ons die Ou Testament lees in die lig van die Nuwe Testament binne die konteks van die Christelike geloof, bely ons dat in Jesus Christus die ware mensheid verskyn het. Omgekeerd, as ons Heb. 2:6 v.v. lees in die lig van Ps. 8, word ons daaraan herinner dat die verlossing in die mens Jesus nie 'n ontvlugting uit die wêreld van menslike sake is nie. Die „wêreld wat kom van Heb. 2:5 moet sy essensiële kontinuiteit met die geskape wêreld van Ps. 8 behou.

Op dieselfde wyse behandel Childs Eks. 2:11-22 (Moses se doodslag van die Egiptenaar en sy vlug na Midian) en kom tot die slotsom: „Ons teks bied nie een klare antwoord op die probleem van die gebruik van geweld ter wille van die saak van geregtigheid nie. Maar dit bring ' $n$ hele reeks sake aan die orde wat inherent aan so ' $n$ handeling is.

Hy behandel ook Spr. 7 onder die opskrif "Proverbs, Ch. 7 and a biblical approach to sex". Spr. 7 word nie in die Nuwe Testament aangehaal nie, en Childs verwys dus na enkele Pauliniese uitsprake. Sy slotsom is: „Die Pauliniese bespreking van die rol van seks in die huwelik is 'n goeie illustrasie van die noodsaak vir die teoloog om die Nuwe Testament in die lig van die Ou Testament te verstaan. Daardeur word twee valse hermeneutiese bewegings vermy, nl. die absolutisering van die Pauliniese leer vir die Christelike etiek in elke eeu, of die verwerping daarvan as ' $n$ verdraaide en tydsgebonde menslike oordeel. Deur die plek daarvan in die normatiewe tradisie te erken en dit te onderwerp aan die kritiek en balans van ander getuies, word ' $n$ teologiese alternatief geopen vir die ernstige gebruik van die Skrif in die lewe van die kerk.

In sy Eksodus-kommentaar (O.T.L. 1974) bevestig Childs sy bedoeling om aan die konstruktiewe elemente van eksegese volle plek te gee naas die deskriptiewe. "The aim of this commentary is to seek to interpret the book of Exodus as canonical scripture within the theological discipline of the Christian Church." Daarmee verwerp hy nie die eis om met die Ou Testamentiese teks te handel in sy 
oorspronklike agtergrond binne die geskiedenis van Israel nie en om gebruik te maak van die resultate van die deskriptiewe eksegese nie. Die stof is soos volg ingedeel:

1. 'n Vertaling van die Hebreeuse teks, diskussie van tekskritiese probleme en besondere aandag aan sintaktiese probleme.

2. 'n Vormkritiese, oorleweringshistoriese analise, 'n nuwe bronneanalise en 'n redaksiegeskiedenis, waarmee hy, in sy woorde, handel met die voorgeskiedenis van die teks. Daarop volg dan die eksegetiese deel.

3. Die Ou Testamentiese konteks van die behandelde teks in sy finale, kanonieke, gestalte.

4. Die Nuwe Testamentiese konteks.

5. Geskiedenis van die eksegese, wat aantoon hoe die teks deur opeenvolgende geslagte verklaarders hanteer is.

6. 'n Teologiese refleksie oor die teks binne die konteks van die Christelike kanon.

Dit is meteen duidelik dat Childs veel verder wil gaan as wat die eksegetiese en teologiese dissiplines in die Bybelwetenskap dusver bereid was om te gaan. Eksegese hou vir hom nie op voordat die teks binne die konteks van die kanon as geheel beluister is nie, en ekscgese eindig nie in Ou Testamentiese of Nuwe Testamentiese teologie nie maar in Bybelse Teologie. Dit is my oortuiging dat ons hier ' $n$ antwoord het op 'n groot deel van die probleem van die Bybelse Teologie en die Eksegese as teologiese dissiplines binne die Christelike kerk. Die kritiek op Childs dat hy ' $n$ analogia fidei tussen die twee testamente veronderstel en dat hy sy beginpunt in die Nuwe Testament neem, ${ }^{5}$ ) lyk my nie geregverdig nie. Trouens, sy standpunt kom baie naby aan die van Bright, wat hom stel op die standpunt dat ons deur middel van die Bybelse Teologie mag hoop om die normatiewe van die insidentele te onderskei binne die Bybelse geloof self, en dat die oorkoepelende teologiese struktuur wat op een of ander wyse aan elke teks vorm gee, die essensiële en normatiewe element in die Ou Testament is, en die een wat dit onherroeplik aan die Nuwe Testament verbind binne die kanon van die Skrif. ${ }^{6}$ ) "Die normatiewe element in die Ou Testament en sy blywende gesag as die Woord van God berus nie op sy wette en gebruike, sy instellings en ou denkpatrone nie, ook nie in die karakters en gebeurtenisse waarvan sy geskiedenis vertel nie, maar in die teologiese struktuur wat elkeen van sy tekste onderskraag en wat in die Nuwe Testament opgevang en aangekondig word as vervul in Jesus Christus." ${ }^{\prime \prime}$ ) Bright kies sy vertrekpunt in die Ou

5) G. Hasel, O.T. Theology: Basic Issues in the Current Debate, 1972, p. 27.

B) J. Bright, The Authority of the Old Testament, 1967, p. 143.

7) Bright, a.w., p. 155 v. 
Testament, maar beklemtoon dat die Christen sy Ou Testament in twee rigtings moet lees: vorentoe saam met die geskiedenis in sy evidente, historiese betekenis, en terugwaarts in die lig van die Nuwe Testamentiese bevestiging daarvan. „We have to refer each of the Old Testament's texts to the New for verdict, whether it be ratification, modification or judgment." ${ }^{8}$ )

Childs het deur sy aanpak van die probleem wel die beskrywing "N.T. Quotation Method"9) verdien, want sowel in sy monografie as in sy kommentaar sien hy kans om die Nuwe Testamentiese konteks te beperk tot dié gedeeltes waar die betrokke Ou Testamentiese teks aangehaal word. Weliswaar gaan hy ook soms anders te werk, maar hier is Bright met sy klem op die teologiese struktuur veel meer ter sake. Childs sal veel meer vrae moet beantwoord voordat 'n mens jou kan bevry van die gedagte dat hy simplisties te werk gaan.

Sowel Bright as Childs dui egter ' $n$ weg aan wat in die toekoms nie ligweg genegeer sal kan word nie. Die hele soeke na 'n sentrum van Ou- en Nuwe Testament en die hele praktyk van die ontwerp van hermeneutiese skemas word irrelevant indien die kanon as konteks aanvaar word en die teologiese struktuur telkens tot gelding gebring word. Die karakter van die „normatiewe” (Bright) of „,konstruktiewe" (Childs) wat die Bybelse Teologie verby die deskriptiewe voer, hou in dat 'n Bybelse Teologie nooit volledig en klaar geskryf sal wees nie.

Kraus kies daarom vir die term „relatiewe teologie": „Terwyl die Bybelse Teologie begin om vas te stel hoe hy daar uit moet sien, betrek hy hom op alle getuienis wat hom gegee is en so op die openbaring wat in die getuienis betuig word. Hierdie ,betrekking' gee aan alle teologiese ondersoek en weergawe die karakter van die ,relatiewe'. Die begrip, relatief' word hier bedoel in die sin van die bedoeling tot betrekking (Bezugsintentionalität) en ook van die relatiwiteit van die verstaansmoontlikhede in die adapteringsproses. Daardeur word alle ondersoek en weergawe in die diens van die veelgestaltige verbum alienum geroep... Voorwerp en inhoud van die ,Bybelse Teologie' kan nóg ' $n$,subjektiewe' nóg ' $n$,objektiewe' wees; nóg 'n geïsoleerde mens nóg 'n geīsoleerde God, maar God en mens in hulle ontmoeting en gemeenskap wat deur God self opgerig en in die openbaringshandeling deurgevoer word... is die ,relatiewe teologie' na sy uitgangspunt en wese ' $n$ aposterioriese gebeure van die sien en verstaan, die begryp en verklaar, dan kan die problematiese werkwyse plek kry dat enersyds die openbaringsen heilsgeskiedenis waaroor die Bybel spreek in sy feitelikheid vasgestel kan word, dat dus feitekennis meegedeel word, en dat andersyds... die ,betekenis' van hierdie geskiedenis na vore

8) Bright, a.w., p. 200.

9) Hasel, a.w., p. 25. 
gebring word." Hierdie „betekenis" impliseer 'n betrokkenheid van die teoloog. "Die verkeer van God met die mens, sy verbond, is vir die ,relatiewe teologie' die korrelasie waarin dit tree", en dit is 'n dinamiese korrelasie wat 'n voortdurende op weg wees impliseer. Twee gesigspunte is dus vir die Bybelse Teologie van belang, $\mathrm{nl}$. dat een persoon nooit alles kan sê en doen nie en dat in elke nuwe geslag die Bybelse Teologie opnuut geskrywe moet word. ${ }^{10}$ )

Kraus aanvaar ook dat 'n „Bybelse Teologie” aangewys is op die tekssamehange wat in die kanon gegee is. Dit is ' $n$ saak wat ook sterk beklemtoon is deur von Rad ten opsigte van die Ou Testamentiese Teologie. Von Rad stel vas dat die voorwerp van die Teologie ,nie die geestesreligieuse wêreld van Israel en sy psigiese samestelling, ook nie sy geloofswêreld is nie ... maar net wat Israel self direk oor Jahwe uitgespreek het." Die teoloog moet van dokument na dokument na die kerugmatiese bedoeling vra. Die geloof van Israel is egter geskiedenisteologies gefundeer, en dit bring die probleem mee dat die histories-kritiese wetenskap se beeld van die geskiedenis iets totaal anders is as die beeld wat Israel self geteken het. "Die historiese ondersoek soek 'n krities versekerde minimum; die kerugmatiese beeld tendeer na 'n teologiese maksimum." $\left.{ }^{11}\right)$ Dat von Rad uiteindelik tog ook self 'n kritiese beeld van die geskiedenis volg, $\mathrm{nl}$. die van die oorleweringsgeskiedenis, is reeds dikwels gestel. ${ }^{12}$ )

Die vraag is of die kritiese eksegese wel sy plek het in die ondersoek na die wording van die kanon, maar die resultate daarvan genegeer kan word in die Bybelse Teologie. Om dit konkreet te stel, is Deuteronomium ' $n$ stuk prediking en herinterpretasie van wetgewing vir opeenvolgende geslagte vanaf die 8 ste tot die 5 de eeu, of is dit, soos dit self voorgee, woorde uit die mond van Moses in die 13de eeu? Beteken die aanvaarding van die finale gestalte van die kanon as die konteks van eksegese en teologie dat die kritiese eksegese op 'n sekere stadium uit die metodiek verdwyn? Hieroor sê Kraus: „Die ,Bybelse Teologie' doen navraag by die eksegese; dit kan net vanuit ' $n$ veranderde uitleggingswerksaamheid geprojekteer en opgebou word. Die eksegetiese proses tendeer na isolering, afgrensing van die kleinste tekseenhede om vorm, oorsprong, tematiek en bedoeling na te vors en dit gaan gepaard met ' $n$ onjuiste afskerm van die ondersoekte gedeelte van die naaste, wyere en wydste konteks... Parallelle word wel opgesoek, maar steeds met die doel om iets by te dra tot verklaring van die betrokke teks. Die vormhistoriese ondersoek begunstig hierdie proses deurdat dit daartoe lei dat die eksegetiese begrip geformaliseer en die kerug-

10) H. J. Kraus, Die Biblische Theologie. Ihre Geschichte und Problematik, 1970, p. 331 v.v.

11) G. von Rad, Theologie des A.T., Band I, 1961, p. 113 v.

12) Vgl. Kraus, a.w., p. 356; W. Harrington, The Path of Biblical Theology, 1973, p. 75 v. 
matiese bedoeling as verbandlose formule uitgebeeld word. Selde vind ' $n$ mens ' $n$ poging om in die ondersoek van die konteks-verbande bybels-teologiese samehange en perspektiewe te ontsluit. Hoe kan ' $n$ mens dit begryp dat bv. by die eksegese van Gen. 15:6 allerlei vermeldenswaardighede en belangrike dinge oor hè,emȳn en sedāqā gesê word maar geen poging gedoen word om die vraag te beantwoord hoe hierdie vers in die Nuwe Testament geresipeer word en waarvolgens na reg die besondere Nuwe Testamentiese verstaanswyse weergegee kan word nie? ... Sonder 'n heroriëntering van die eksegetiese wetenskap in die horison van die konteksope ondersoek en in die opsoek van bybels-teologiese perspektiewe is die on derneem van 'n Bybelse Teologie nie denkbaar nie." ${ }^{13}$ ) Dit sal beteken dat die eksegese self die bo gestelde vraag ten opsigte van Deut. moet beantwoord. (Hier sal nie alleen ,kerugmatiese bedoeling" nagevors moet word nie, maar ook die gestalte van "Moses": Beteken die formules wat aan Moses wetgewing toeskryf, aan Dawid liedere, aan Salomo wysheidsuitsprake, werklik dat die outeur daarmee aan outeurskap in ons sin van die woord dink?)

Kraus wys daarop dat ons ver verwyderd staan van die realisering van ' $n$ Bybelse Teologie. Daar is voorarbeid nodig op ' $n$ wye, onbegrensde gebied. Hy wys op die noodsaak van begripstudie, stel die vraag of die tussen-testamentêre Jodendom genoeg aandag kry in bybels-teologiese studies en wys op die probleem van die Bybelse geskiedenisbegrip wat steeds nie genoegsaam opgehelder is nie. Vireers moet dit dus daarom gaan, versigtig en beskeie, dat in die Ou Testamentiese en Nuwe Testamentiese wetenskap 'n eerste tree gegee word binne die nuut waargenome proses van Bybels-teologies georiënteerde eksegese: dat dus nie net na die teologie van Jesaja of Paulus gevra word nie, maar dat reeds in so ' $n$ begrens de behandeling die perspektief op die konteks-ope interpretasie met die oog op bybels-teologiese samehange oopgehou word. ' $n$ Volgende stap is histories-krities georiënteerde lengtesnitte en perspektiviese studies, wat met ' $n$ tema-bepaalde vraagstelling deur die Ou- en Nuwe Testament getrek word en ook die Jodendom tussen die testamente deurdringend ondersoek. So sal die menigvuldigheid van die bybelse getuienis aan die lig kom, en sal ook die vraag na die eenheíd gestel kan word, wat net kan wees 'n vraag na die Een. ${ }^{14}$ ) Daarmee het Kraus afgesien van die gedagte van ' $n$ sentrum van Ou- of Nuwe Testament.

Waar ' $n$ sentrum of heersende motief gekies is, was dit ter wille van sistematiek. Eichrodt het die verbond gekies, Sellin die heiligheid van God, Köhler God as Heer, Wildberger die verkiesing van Israel as godsvolk, Seebass God as die regeerder, Klein die koninkryk van God, Fohrer die regering van God en die gemeenskap

13) Kraus, a.w., p. 369 v.v.

14) Kraus, a.w., p. 371 v.v. Vgl. ook Hasel, a.w., p. 81 v.v. 
tussen God en mens, Vriezen die gemeenskap. ${ }^{15}$ ) Eintlik is die sentrum gegee wanneer teologie spreke oor God beteken. ${ }^{16}$ ) Dit kan alleen God wees, maar dan God in verhouding tot die mens, soos Kraus in navolging van ander beklemtoon.

As ons, soos Childs vra, die dialektiese verhouding tussen die testamente laat geld en nie met ' $n$ vooraf aanvaarde sisteem na die stof van die Bybelse Teologie toe kom nie, en dus ook nie 'n keuse vir 'n sentrum maak nie, beteken dit nog nie dat ons nie sistematies te werk moet gaan nie. Een of ander vorm van sistematiese aanbieding is nodig wanneer resultate byeengebring en aangebied word.

Bright definieer Bybelse Teologie soos volg: „'n Induktiewe, beskrywende dissipline, sinteties in sy benadering, wat, op die basis van 'n grammaties-historiese studie van die Bybelteks, poog om in sy eie terminologie en strukturele eenheid die teologie weer te gee wat in die Bybel uitgespreek word." "Ou Testamentiese Teologie het die funksie om 'n samehangende beskrywing te gee van die geloof van die Ou Testament in sy strukturele eenheid." ${ }^{17}$ ) Die taak van die Bybelse (of Ou- of Nuwe Testamentiese Teologie) word bemoeilik deurdat die godsdiens van geen van die testamente sistematies uitgespel word nie. Tog. sê Bright, is daar 'n oorkoepelende eenheid in albei testamente en is daar ' $n$ historiese en teologiese verband tussen die twee. In sy belangrike tema-studie ${ }^{18}$ ) sê hy: „Die historiese benadering is gekies omdat ... bybelse teologie op geen ander wyse behandel kan word nie. Maak dit abstrak, bespreek dit as ' $n$ sisteem van idees los van geskiedenis, en dit is nie meer bybelse teologie nie." Hy vereenselwig hom dus in dié opsig met von Rad wat sy gedagte so uitdruk: "Die mees legitieme vorm van teologiese spreke oor die Ou Testament is steeds nog die navertelling", en dan ook inderdaad 'n teologie bied wat 'n reeks teologieë in oorleweringshistoriese volgorde bevat. Die verskil is dat Bright dit doen aan die hand van 'n tema, en dat von Rad berus by die kategorie geskiedenis, en dan 'n spesifiek gekonstrueerde oorleweringsgeskiedenis. Dat von Rad ' $n$ indrukwekkende werk gelewer het, staan vas. Tog sou ' $n$ mens ' $n$ verdere twee stappe wou sien, $n l$. ' $n$ dwarssnit aan die einde van die navertelling en ' $n$ praktiese deurvoering van die imposante hermeneutiek wat in die derde hoofdeel van sy Teologie aangebied word. Von Rad (lengtesnit) plus Eichrodt (dwarssnit) maak dus tesame ook nog nie 'n Bybelse Teologie uit nie. Die byvoeging van 'n Nuwe Testamentiese Teologie sou dit ook nog nie bewerk nie. Wat nodig is, is ' $n$ aanpak van die saak wat van die begin af op die konteks van die hele kanon gerig is. Dit lyk my nie korrek om so kategories soos Bright die historiese aanbieding tot enigste moontlikheid te verhef nie. Dit

15) Vgl. Hasel, a.w., p. 49 v.v.

${ }_{16}$ Vgl. W. Zimmerli, Grundriss der A.T. Theologie, 1972, p. 9 v.

17 Bright, a.w., p. 115.

18) J. Bright, The Kingdom of God, 1953, p. 11. 
moet moontlik wees om uiteindelik ook sinteties te werk te gaan en te sistematiseer. Indien dit nie gebeur nie, het ons wel die teologieë van verskillende tydvakke en openbaringsdraers, maar nooit 'n Bybelse Teologie nie.

Die debat gaan voort. Intussen is daar riglyne wat na vore gekom het wat nie meer ontwyk kan word nie.

Die eerste is die behoefte aan 'n Bybelse Teologie wat die kanon as konteks het. Dit beteken dat ons nie kan volstaan met 'n teologie van die Ou- of die Nuwe Testament nie; maar dit is nie al nie: ook nie met 'n Ou- of Nuwe Testamentiese Teologie wat nie die kanon as geheel as konteks het nie. Die voorbereidende werk wat hier nodig is, is 'n Ou Testamentiese Teologie en 'n Nuwe Testamentiese Teologie wat reeds Bybelse Teologie is.

Dit bring ons meteen by die tweede riglyn, $\mathrm{nl}$. dat die verhouding tussen die twee testamente nie op een of ander wyse ontwerp moet word nie, maar 'n gegewene is wat gevind moet word deur die eksegese binne die konteks van die kanon. So 'n eksegese wat deurstoot na die konteks van die kanon as geheel en dus die teologiese struktuur uitwerk wat Ou- en Nuwe Testamente tesame oorkoepel en verbind, kan die geskrifte van die tussen-testamentêre tyd nie negeer nie. Hierdie geskrifte vorm wel nie deel van die kanon nie, maar dra baie by tot opheldering van die vraag hoe die $\mathrm{Ou}$ Testament in die Nuwe Testament opgeneem word.

As derde riglyn moet gestel word dat die grammaties-historiese eksegese steeds die enigste weg van verantwoordelike omgang met die Skrif bly. Die eksegese moet hom egter bewus bly van die volle konteks van die woorde waarin hy probeer dring, en aan die Bybelse Teologie die materiaal vir sy arbeid lewer.

'n Vierde riglyn is dat die sentrum van die Skrif eerder gevind word in 'n lewende verhouding as in ' $n$ idee. Die sistematiese aanbieding van die resultate van die Bybelse Teologie kan die beste geskied binne die verhouding tussen God en mens. Die kanon kan egter nouliks twee sentra hê, God vir die Ou en Christus vir die Nuwe Testament. Vir die kerk is die sentrum van die kanon in gegewene. Die verhouding tussen God en mens is ' $n$ verhouding deur Christus heen. Dit beteken nie 'n .,Christologiese" lees van die Ou Testament nie, maar wel die wete dat die konteks van die kanon die konteks is waarbinne die handeling van God met die mens sy finaliteit in die gekruisigde en opgestane Christus vind.*

* Mededeling aan die Predikantevergadering van die Nederduitsch Hervormde Kerk, Pretoria, 15 September 1976. 